Tetsuro Sohda $\cdot$ Kaoru Iwata $\cdot$ Hidenobu Soejima

Seiichiro Kamimura • Hiroshi Shijo • Kankatsu Yun

\title{
In situ detection of insulin-like growth factor II (IGF2) and H19 gene expression in hepatocellular carcinoma
}

Received: July 25, 1997/Accepted: October 22, 1997

\begin{abstract}
To assess the relationship between insulin-like growth factor II (IGF2) and H19 gene expression at the cellular level, we have examined the distribution of IGF2 and $H 19$ mRNA by means of in situ hybridization in hepatic malignancies consisting of hepatocellular carcinoma (HCC), cholangiocellular carcinoma (CCC), and metastatic liver cancer (MLC). In HCC, 15 of 27 tumors (56\%) and 11 of 27 tumors (41\%) demonstrated increased IGF2 and H19 gene expression, respectively. Of 16 HCCs with increased expression of either IGF2 or H19, 10 tumors coexpressed both transcripts at comparable levels. Moreover, the spatiotemporal distribution and the cellular localization of the two gene transcripts were almost identical, suggesting the presence of a reciprocal relation between $I G F 2$ and $H 19$. In addition, 5 HCCs showed increased IGF2 expression without concomitant $H 19$ expression, whereas 1 HCC showed increased $H 19$ expression without IGF2 transcripts. However, 11 HCCs showed no IGF2 or H19 expression. On the other hand, neither IGF2 transcripts nor $H 19$ transcripts were detected in 2 CCCs or 10 MLCs studied. The data suggest that IGF2 and/or $H 19$ gene expression may be characteristic of some HCCs.
\end{abstract}

Key words $I G F 2 H 19$ • Gene · Hepatocellular carcinoma • In situ hybridization

\section{Introduction}

Insulin-like growth factor II (IGF2), whose gene is located on chromosome $11 \mathrm{p} 15.5$, is a growth factor believed to be important in fetal growth and development (Moses et al.

T. Sohda $(\triangle) \cdot$ K. Iwata $\cdot$ S. Kamimura $\cdot$ H. Shijo

First Department of Internal Medicine, School of Medicine, Fukuoka University, 7-45-1 Nanakuma, Jonan-ku, Fukuoka 814-0180, Japan

Tel. +81-92-801-1011; Fax +81-92-865-5656

e-mail: hh038131@msat.fukuoka-u.ac.jp

H. Soejima $\cdot$ K. Yun

Department of Pathology, University of Otago Medical School,

Dunedin, New Zealand
1980; Brown et al. 1986; Humbel 1990). The human IGF2 gene is one of a dozen genes which are subject to genomic imprinting, with the paternal allele expressed and the maternal allele silent. The IGF2 gene is a complex transcriptional unit that contains four different promoters (P1-P4) (Sussenbach et al. 1991; van Dijk et al. 1991). During fetal life, a high level of $I G F 2$ transcript is expressed mainly from the P2-P4, fetal-type promoters, and the resulting IGF2 serves as a growth factor in several embryonic tissues including fetal liver. In contrast, adult liver demonstrates loss of imprinting (LOI) of IGF2 which is derived from P1, leading to biallelic $I G F 2$ expression, while $I G F 2$ transcripts derived from $\mathrm{P} 2-\mathrm{P} 4$ show markedly decreased expression, although they remain monoallelically expressed $(\mathrm{Vu}$ and Hoffman 1994; Ekström et al. 1995).

It has been reported that IGF2 plays a role in the pathogenesis of a variety of neoplasms (LeRoith et al. 1995). Since increased expression of IGF2 in hepatocellular carcinoma (HCC) was originally described by Cariani et al. (1988), several investigators have reported that IGF2 may play a role in the development of HCC (D'Arville et al. 1991; Lamas et al. 1991; Sohda et al. 1996).

The $H 19$ gene, which is located $200 \mathrm{~kb}$ downstream of $I G F 2$, has also been implicated in tumor development and is believed to function as a tumor suppressor (Zhang and Tycko 1992; Hao et al. 1993). H19 has also been shown to be imprinted, with the maternal allele being expressed and the paternal silent, in contrast to $I G F 2$, for which the reverse situation applies. This unique reciprocal relationship, along with the observation that IGF2 and H19 genes are extensively coexpressed during human embryonic/fetal development (Ohlsson et al. 1994), has lead to the so-called enhancer competition model hypothesis. This model proposes that there exists a regulatory element near the IGF2/ $H 19$ loci that acts as a switch to allow either IGF2 or H19 expression (Pfeifer and Tilghman 1994).

It was recently reported that the expression of $I G F 2$ and H19 in HCC were related to each other (Takeda et al. 1996; Li et al. 1997). However, it remains unclear whether high expression of $I G F 2$ and $H 19$ occurs within a single cell. In this study, to assess the relationship between IGF2 and H19 
gene expression at the cellular level in HCC, we carried out in situ hybridization and compared the level and the localization of $H 19$ transcripts. In addition, we examined expression of these transcripts in other liver malignancies: cholangiocellular carcinoma (CCC) and metastatic liver cancer (MLC). The results demonstrated that increased levels of $I G F 2$ expression were detected in approximately half of the HCCs, and the distribution and the intensity of IGF2 transcripts showed a close resemblance to those of $H 19$, whereas other liver cancers showed no detectable levels of IGF2 or $\mathrm{H} 19$ gene expression.

\section{Materials and methods}

\section{Tissue specimens}

The present study comprised 27 HCCs, 2 CCCs, and 10 MLCs, all of which were from an autopsy file of the Fukuoka University Hospital. The diagnosis was based upon histological findings and clinical examination. Routine staining was performed to evaluate histological type. HCC was histologically graded according to the classification of Edmondson and Stainer (1954), and the results are summarized in Table 1. Of $27 \mathrm{HCCs}, 14$ were positive for hepatitis $\mathrm{C}$ virus antibody (HCVAb) only, 6 were positive for hepatitis B surface antigen (HBsAg) only, 1 was positive for both
HBsAg and HCVAb, and 6 were negative for both HBsAg and HCVAb (Table 1).

All liver samples were fixed in buffered $10 \%$ formalin and embedded in paraffin. Serial 5-mm-thick sections were cut and mounted on slides coated with 2\% 3aminopropyltriethoxysilane. Slides were then heated at $60^{\circ} \mathrm{C}$ for $2 \mathrm{~h}$ and stored at room temperature until use.

RNA probes

The human IGF2 was a 559-bp fragment corresponding to nucleotides 256-815 obtained from cDNA of phigh2 cloned into pGEM-3. The $H 19$ clone correspond to a EcoRI-SacI fragment of human $H 19$ cDNA cloned into pGEM-7ZF(+). Sense and antisense RNA probes were transcribed from linearized templates using SP6 and T7 RNA polymerases (Promega, Madison, WI, USA), and radiolabeling with $\left[{ }^{35} \mathrm{~S}\right]$-CTP (Amersham, Buckinghamshire, UK).

In situ hybridization

In situ hybridization analyses were performed according to the methods previously described (Wilkins et al. 1989). Briefly, hybridization was carried out in a solution containing $50 \%$ formamide, $2 \times \mathrm{SSC}, 0.15 \mathrm{M} \mathrm{NaCl}, 0.2 \mathrm{mg} / \mathrm{ml}$ Escherichia coli tRNA, $1 \mathrm{mg} / \mathrm{ml}$ degraded herring sperm DNA, $0.1 \mathrm{mg} / \mathrm{ml}$ bovine serum albumin, $10 \%$ polyethylene

Table 1 Clinical, histological and in situ hybridization summary of hepatocellular carcinomas

\begin{tabular}{|c|c|c|c|c|c|}
\hline Cases & Age/Sex & Virus markers & Non-T & $\mathrm{T}^{\mathrm{a}}$ & $I G F 2 / H 19$ \\
\hline 1 & 69/M & $\operatorname{HCVAb}(+)$ & $\mathrm{LC}$ & II & $+++/+++$ \\
\hline 2 & $64 / \mathrm{M}$ & $\operatorname{HCVAb}(+)$ & $\mathrm{LC}$ & $\mathrm{I}$ & $++/++$ \\
\hline 3 & $26 / \mathrm{F}$ & $\operatorname{HBsAg}(+)$ & $\mathrm{LC}$ & III & $++/++$ \\
\hline 4 & $17 / \mathrm{F}$ & $\operatorname{HBsAg}(-), \operatorname{HCVAb}(-)$ & Normal & II & $++/++$ \\
\hline 5 & 49/M & $\operatorname{HBsAg}(+)$ & $\mathrm{CAH}$ & III & $++1-$ \\
\hline 6 & $57 / \mathrm{M}$ & $\operatorname{HCVAb}(+)$ & $\mathrm{LC}$ & $\mathrm{I}$ & $+/+$ \\
\hline 7 & $59 / \mathrm{M}$ & $\operatorname{HCVAb}(+)$ & $\mathrm{LC}$ & II & $+/+$ \\
\hline 8 & $68 / \mathrm{M}$ & $\operatorname{HCVAb}(+)$ & $\mathrm{LC}$ & I & $+/+$ \\
\hline 9 & $68 / \mathrm{M}$ & $\operatorname{HCVAb}(+)$ & $\mathrm{LC}$ & II & $+/+$ \\
\hline 10 & $44 / \mathrm{M}$ & $\operatorname{HBsAg}(+)$ & $\mathrm{CAH}$ & III & $+/+$ \\
\hline 11 & $68 / \mathrm{M}$ & $\operatorname{HBsAg}(-), \operatorname{HCVAb}(-)$ & $\mathrm{LC}$ & II & $+/+$ \\
\hline 12 & $68 / \mathrm{M}$ & $\mathrm{HCVAb}(+)$ & $\mathrm{LC}$ & $\mathrm{I}$ & $+1-$ \\
\hline 13 & $61 / \mathrm{M}$ & $\operatorname{HCVAb}(+)$ & $\mathrm{LC}$ & II & $+1-$ \\
\hline 14 & $60 / \mathrm{M}$ & $\operatorname{HCVAb}(+)$ & $\mathrm{LC}$ & II & $+1-$ \\
\hline 15 & $75 / \mathrm{F}$ & $\operatorname{HCVAb}(+)$ & $\mathrm{LC}$ & III & $+1-$ \\
\hline 16 & $75 / \mathrm{M}$ & $\operatorname{HBsAg}(-), \operatorname{HCVAb}(-)$ & $\mathrm{LC}$ & II & $-/++$ \\
\hline 17 & $60 / \mathrm{M}$ & $\mathrm{HCVAb}(+)$ & $\mathrm{LC}$ & II & $-1-$ \\
\hline 18 & $66 / \mathrm{F}$ & $\operatorname{HCVAb}(+)$ & $\mathrm{LC}$ & I & $-1-$ \\
\hline 19 & $62 / \mathrm{M}$ & $\operatorname{HCVAb}(+)$ & $\mathrm{LC}$ & II & $-1-$ \\
\hline 20 & $59 / \mathrm{M}$ & $\operatorname{HCVAb}(+)$ & $\mathrm{LC}$ & II & $-1-$ \\
\hline 21 & $51 / \mathrm{M}$ & $\operatorname{HBsAg}(+)$ & $\mathrm{LC}$ & III & $-1-$ \\
\hline 22 & $40 / \mathrm{F}$ & $\operatorname{HBsAg}(+)$ & $\mathrm{LC}$ & II & $-1-$ \\
\hline 23 & $45 / \mathrm{M}$ & $\operatorname{HBsAg}(+)$ & $\mathrm{LC}$ & I & $-1-$ \\
\hline 24 & $87 / \mathrm{M}$ & $\operatorname{HBsAg}(-), \operatorname{HCVAb}(-)$ & $\mathrm{LC}$ & II & $-1-$ \\
\hline 25 & $62 / \mathrm{M}$ & $\operatorname{HBsAg}(-), \operatorname{HCVAb}(-)$ & $\mathrm{LC}$ & I & $-1-$ \\
\hline 26 & $67 / \mathrm{M}$ & $\operatorname{HBsAg}(-), \operatorname{HCVAb}(-)$ & $\mathrm{LC}$ & III & $-1-$ \\
\hline 27 & $77 / \mathrm{M}$ & $\operatorname{HBsAg}(+), \operatorname{HCVAb}(+)$ & $\mathrm{LC}$ & I & $-1-$ \\
\hline
\end{tabular}

${ }^{a}$ Edmondson and Steiner's classification.

Non-T, non-tumorous liver; T, tumorous lesion; LC, liver cirrhosis; CAH, chronic active hepatitis.

+++ , Strong positivity; ++ , moderate; + , weak; - , slight or nil. 
glycol, $0.2 \mathrm{M}$ dithiothreitol, and $\left.{ }^{35} \mathrm{~S}\right]$-CTP-labeled antisense or sense RNA probe $(40,000 \mathrm{cpm} / \mathrm{ml})$ at $50^{\circ} \mathrm{C}$ overnight. After hybridization, the slides were washed in $50 \%$ formamide, $2 \times \mathrm{SSC}$ at $52^{\circ} \mathrm{C}$ and in $2 \times \mathrm{SSC}$ at room temperature. The slides were then incubated in RNase A solution at $37^{\circ} \mathrm{C}$ for $30 \mathrm{~min}$. For autoradiography, slides were dipped into nuclear emulsion (Amersham) and exposed in light-tight boxes at $4^{\circ} \mathrm{C}$ for 2 weeks. After development, the slides were counterstained with hematoxylin-eosin.

\section{Results}

In situ mRNA hybridization in HCC

Among the 27 HCCs examined by in situ hybridization, increased expression of the IGF2 gene was observed in 15 HCC cases (56\%), which consisted of 10 of 14 cases associated with hepatitis $\mathrm{C}$ virus (HCV), 3 of 6 cases associated with hepatitis B virus (HBV), and 2 of 6 cases negative for both $\mathrm{HBV}$ and $\mathrm{HCV}$, and did not include the single case with both HBV and HCV. On the other hand, an increased level of $H 19$ transcripts was detected in $11(41 \%)$ of 27
HCCs. These 11 tumors included 6 of 14 cases positive for $\mathrm{HCV}, 2$ of 6 positive for HBV, and 3 of 6 negative for both $\mathrm{HBV}$ and $\mathrm{HCV}$, and also excluded the case with both HBV and HCV. Collectively, 16 of 27 HCCs showed increased expression of either the IGF2 or the H19 gene. Among these 16 HCCs, 10 tumors showed both transcripts, while 5 produced only $I G F 2$ transcripts, and 1 had only $H 19$ transcripts. There appeared to be no obvious, statistically significant correlations among tumors with or without IGF2 and/or H19 expression, in terms of histological and clinical parameters.

With respect to the spatial or cellular localization, IGF2 and $H 19$ transcripts were detected specifically in the cytoplasm of HCC cells. Significant levels of hybridization signal were detected in less-well-differentiated HCC cells which were located in the periphery of HCC tumor nodules, whereas well-differentiated tumor cells in the central area showed no detectable level of transcripts (Fig. 1). On the other hand, regenerative hepatocytes in cirrhotic liver from nontumorous areas contained low levels of transcripts. All of the 10 tumors with increased IGF2 and H19 transcripts showed almost identical cellular localization of the two transcripts, strongly suggesting that the tumor cells coexpress both transcripts. Furthermore, the levels of the two gene transcripts in these 10 HCCs appeared to be closely and positively correlated (Table 1 ).
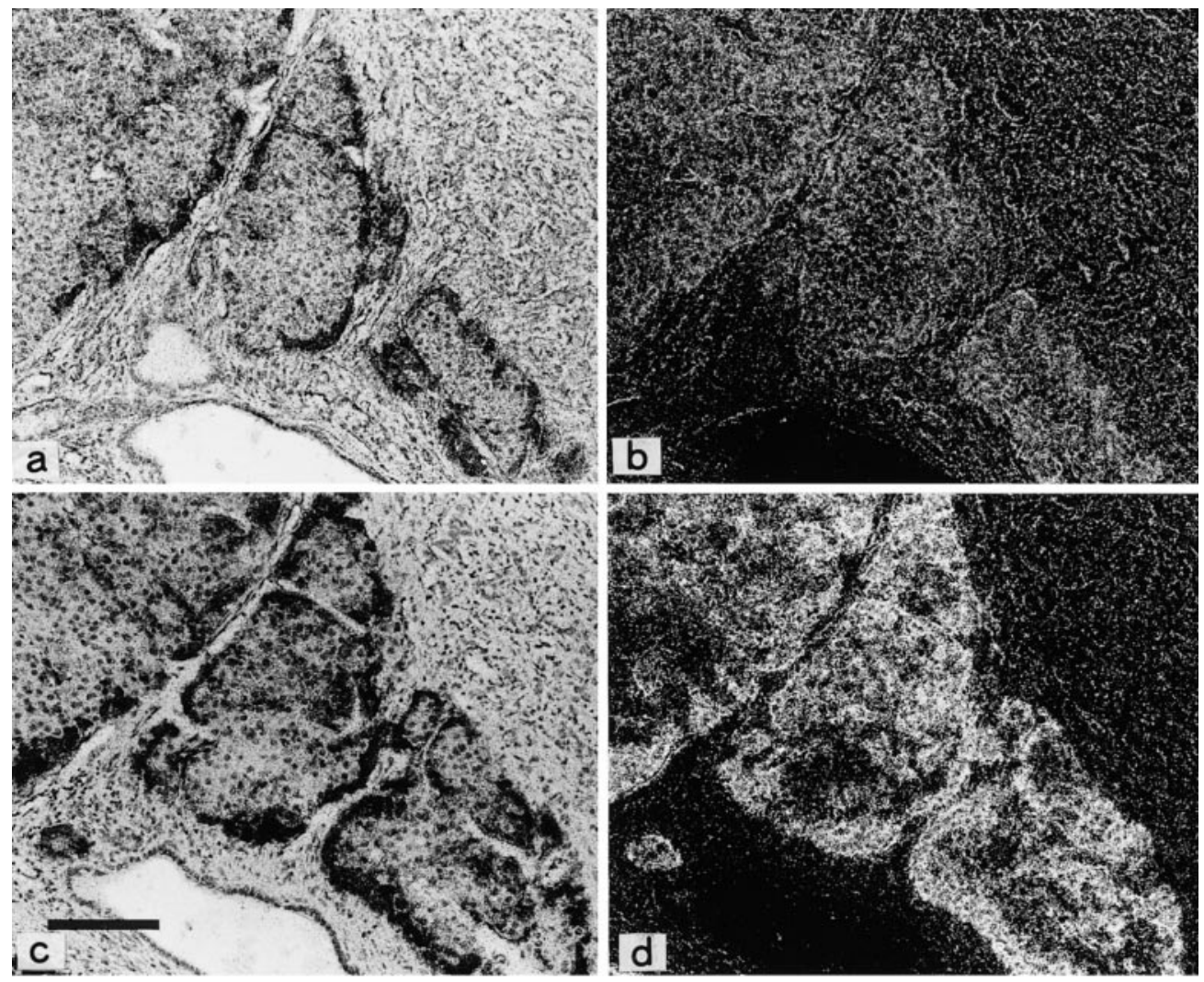

Fig. 1 In situ hybridization analyses of IGF2 and $H 19$ genes in hepatocellular carcinoma (HCC). $\mathbf{a}$ and $\mathbf{c}$ are bright field photomicrographs; $\mathbf{b}$ and $\mathbf{d}$ are the respective corresponding dark field photomicrographs. High levels of IGF2 transcripts were observed in the cytoplasm of HCC cells that are located at the periphery of tumor nodules (a and $\mathbf{b})$. A serial section demonstrates that increased levels of $H 19$ transcripts were also detected in the HCC cells that are located at periphery of tumor nodules (c and d). The localization pattern of the H19 gene was almost identical to that of IGF2. Bar, $200 \mathrm{~nm}$ 
Table 2 Clinical and in situ hybridization summary of other liver cancers

\begin{tabular}{cllll}
\hline Cases & Age/Sex & Origins & Histology & IGF2/H19 \\
\hline 1 & $66 / \mathrm{M}$ & Lung & Squamous cell carcinoma & $-/-$ \\
2 & $61 / \mathrm{M}$ & Lung & Adenocarcinoma & $-/-$ \\
3 & $54 / \mathrm{F}$ & Uterine cervix & Squamous cell carcinoma & $-/-$ \\
4 & $47 / \mathrm{F}$ & Uterine cervix & Adenosquamous cell carcinoma & $-/-$ \\
5 & $69 / \mathrm{M}$ & Kidney & Renal cell carcinoma & $-/-$ \\
6 & $54 / \mathrm{F}$ & Iliac bone & Fibroblastic osteosarcoma & $-/-$ \\
7 & $57 / \mathrm{M}$ & Hypopharynx & Squamous cell carcinoma & $-/-$ \\
8 & $84 / \mathrm{M}$ & Stomach & Adenocarcinoma & $-/-$ \\
9 & $73 / \mathrm{F}$ & Pancreas & Tubular adenocarcinoma & $-/-$ \\
10 & $67 / \mathrm{M}$ & Colon & Adenocarcinoma & $-/-$ \\
11 & $50 / \mathrm{M}$ & Liver & Cholangiocellular carcinoma & $-/-$ \\
12 & $78 / \mathrm{F}$ & Liver & Cholangiocellular carcinoma & $-/-$ \\
\hline
\end{tabular}

,- slight or nil.

\section{Expression of IGF2 and $H 19$ in other liver cancers}

Tumors from 10 MLCs were also included in this study. The primary sites are shown in Table 2. Neither IGF2 nor H19 transcripts were expressed in liver metastases or primary tumors, while low levels of both transcripts were detected in the hepatocytes from nonneoplastic lesions. Similarly, in 2 CCCs, neither IGF2 nor H19 transcripts were detected (data not shown).

\section{Discussion}

We have examined the expression patterns of the $I G F 2$ and $\mathrm{H} 19$ genes in $\mathrm{HCC}$ by means of in situ hybridization. It is generally known that the formalin-fixed section technique is also available to perform in situ mRNA hybridization. However, to avoid the degradation of RNA by endogenous RNase, we have used liver sections which were fixed in formalin within $3 \mathrm{~h}$ of cardiac arrest. Moreover, we confirmed the specificity by: (1) pretreatment of tissue sections with RNase A $(100 \mathrm{mg} / \mathrm{ml})$ for $1 \mathrm{~h}$ at $37^{\circ} \mathrm{C}$ before hybridization; (2) hybridization with sense probes; and (3) hybridization of fetal liver samples as positive controls (data not shown).

HCC is known to be one of the neoplasms which produce IGF2. Nardone et al. (1996) reported IGF2 expression in HCCs associated with HCV. In addition, Su et al. (1994) reported a role for IGF2 in HCC associated with HBV, i.e., products of the integrated hepatitis $\mathrm{B} x$ gene may activate the IGF2 gene. The present study found increased IGF2 expression in $56 \%$ of HCCs. The increased expression of $I G F 2$ is envisaged to be advantageous for tumor growth. Most of the growth factors produced by tumor cells are thought to promote the growth of the tumor itself (Heldin and Westermark 1984; Sporn and Roberts 1985). In the present study, the high level of hybridization signal was detected in less-well-differentiated tumor cells but not in well-differentiated cells, suggesting that IGF2 may act as an autocrine or paracrine growth factor. This notion is supported by our recent observation in that IGF2 protein and Ki-67 antigen, a proliferation marker, are codetected in less-well-differentiated tumor cells (Sohda et al. 1997). We have also previously demonstrated that in HCC, the increased IGF2 mRNA is transcribed largely from the fetal type promoter, $\mathrm{P} 3$, rather that the adult type promoter, P1, and that the level of IGF2 mRNA is comparable to that of IGF2 protein in tumor cells, indicating that IGF2 production is primarily regulated at the gene transcriptional level without significant posttranscriptional modification (Sohda et al. 1996). These reports by us and others suggest that IGF2 may play a primary role as an autocrine growth factor in $\mathrm{HCC}$.

The $H 19$ gene, located telomeric to IGF2 on chromosome $11 \mathrm{p} 15.5$, which is frequently involved in loss of heterozygosity (LOH) in a variety of cancers, including HCC (Viel et al. 1992; Winqvist et al. 1993; Baffa et al. 1996; Besnard-Guérin et al. 1996), is subject to genomic imprinting with maternal gene expression only. H19 transcripts were detected in $41 \%$ of HCCs. Tumors expressing the two transcripts showed similar cellular localization patterns for H19 and IGF2 transcripts, a result consistent with the enhancer competition model. According to the model, the regulatory units telomeric to $I G F 2$ and $H 19$ genes control a switch for either IGF2 or H19 expression, thus leading to reciprocal expression of the two genes (Pfeifer and Tilghman 1994). This model appears to fit well in endodermal tissues such as liver, or in the endomesodermal mixed tissue including gut, kidney, and lung. In other tissues, such as placenta, skeletal muscle, and brain, the model does not fit, suggesting the involvement of other factors in the control of $H 19$ and IGF2 expression. The model gains support from the observation that biallelic expression of $I G F 2$ appears to be associated with decreased expression of H19 in childhood tumors such as Wilms' tumor and hepatoblastoma, suggesting that $H 19$ plays a role in tumor suppression as a cis-acting repressor of IGF2 ( $\mathrm{Li}$ et al. 1995; Steenman et al. 1994; Moulton et al. 1994). We have reported that early-stage placentae showed biallelic H19 and monoallelic $I G F 2$ expression in the same placental trophoblasts (Jinno et al. 1995).

Our present study indicated that neither IGF2 nor $H 19$ transcripts were detected in 11 of 27 HCCs and that comparable levels of the two gene transcripts were seen in 10 tumors $(37 \%)$. On the other hand, 5 tumors $(18.5 \%)$ were 
associated with the upregulation of IGF2 and the downregulation of H19. One tumor (4.5\%) was associated with the downregulation of IGF2 and the upregulation of H19. Therefore, our data suggest that, in contrast to Wilms' tumor, in HCC, H19 may have a limited role, and that gene activation of IGF2 and $H 19$ may be involved in the complicated mechanism of hepatocarcinogenesis.

\section{References}

Baffa R, Negrini M, Mandes B, Rugge M, Ranzani GN, Hirohashi S, Croce CM (1996) Loss of heterozygosity for chromosome 11 in adenocarcinoma of the stomach. Cancer Res 56:268-272

Besnard-Guérin C, Newsham I, Winqvist R, Cavenee WK (1996) A common region of loss of heterozygosity in Wilms' tumor and embryonal rhabdomyosarcoma distal to the D11S988 locus on chromosome 11p15.5. Hum Genet 97:163-170

Brown AL, Graham DE, Nissley SP, Hill DJ, Strain AJ, Rechler MM (1986) Developmental regulation of insulin-like growth factor II mRNA in different rat tissues. J Biol Chem 261:13144-13150

Cariani E, Lasserre C, Seurin D, Hamelin B, Kemeny F, Franco D, Czech MP, Ullrich A, Brechot C (1988) Differential expression of insulin-like growth factor II mRNA in human primary liver cancers, benign liver tumors, and liver cirrhosis. Cancer Res 48:6844-6849

D'Arville CN, Nouri-Aria KT, Johnson P, Williams R (1991) Regulation of insulin-like growth factor II gene expression by hepatitis B virus in hepatocellular carcinoma. Hepatology 13:310-315

Edmondson HA, Steiner PE (1954) Primary carcinoma of the liver: A study of 100 cases among 48900 necropsy. Cancer 7:462-503

Ekström TJ, Cui H, Li X, Ohlsson R (1995) Promoter-specific IGF2 imprinting status and its plasticity during human liver development. Development 121:309-316

Hao Y, Crenshaw T, Moulton T, Newcomb E, Tycko B (1993) Tumorsuppresser activity of H19 RNA. Nature 365:764-767

Heldin CH, Westermark B (1984) Growth factors: Mechanism of action and relation to oncogenes. Cell 37:9-20

Humbel RE (1990) Insulin-like growth factor I and II. Eur J Biochem 190:445-462

Jinno Y, Ikeda Y, Yun K, Maw M, Masuzaki H, Fukuda H, Inuzuka K, Fujishita A, Ohtani Y, Okimoto T, Ishimaru T, Niikawa N (1995) Establishment of functional imprinting of the $\mathrm{H} 19$ gene in human developing placentae. Nat Genet 10:318-324

Lamas E, LeBail B, Housset C, Boucher O, Bréchot C (1991) Localization of insulin-like growth factor-II and hepatitis B virus mRNAs and proteins in human hepatocellular carcinomas. Lab Invest 64:98104

LeRoith D, Baserga R, Helman L, Roberts CT Jr (1995) Insulin-like growth factors and cancer. Ann Intern Med 122:54-59

Li X, Adam G, Cui H, Stanstedt B, Ohlsson R, Ekström TJ (1995) Expression, promoter usage and parental imprinting status of insulin-like growth factor II (IGF2) in human hepatoblastoma: uncoupling of IGF2 and H19 imprinting. Oncogene 11:221-229

Li X, Nong Z, Ekström C, Larsson E, Nordlinder H, Hofmann WJ, Trautwein C, Odenthal M, Dienes HP, Ekström TJ, Schirmacher P (1997) Disrupted IGF2 promoter control by silencing of promoter P1 in human hepatocellular carcinoma. Cancer Res 57:2048-2054

Moses AC, Nissley SP, Short PA, Rechler MM, White RM, Knight AB, Higa OZ (1980) Increased levels of multiplication stimulation activ- ity, an insulin-like growth factor, in fetal rat serum. Proc Natl Acad Sci USA 77:3649-3653

Moulton T, Crenshow T, Hao Y, Moosikasuwan J, Lin N, Dembizer F, Hensle T, Weiss L, McMorrow L, Loew T, Kraus W, Gerald W, Tycko B (1994) Epigenetic lesions at the H19 locus in Wilms' tumour patients. Nat Genet 7:440-447

Nardone G, Romano M, Calabro A, Pedone PV, de Sio I, Persico M, Budillon G, Bruni CB, Riccio A, Zarrilli R (1996) Activation of fetal promoters of insulin-like growth factor II gene in hepatitis $\mathrm{C}$ virusrelated chronic hepatitis, cirrhosis, and hepatocellular carcinoma. Hepatology 23:1304-1312

Ohlsson R, Hedborg F, Holmgren L, Walsh C, Ekström TJ (1994) Overlapping patterns of IGF2 and H19 expression during human development: biallelic $I G F 2$ expression correlates with a lack of $H 19$ expression. Development 120:361-368

Pfeifer K, Tilghman SM (1994) Allele specific gene expression in mammals: the curious case of the imprinted RNAs. Genes Dev 8:18671874

Sohda T, Yun K, Iwata K, Soejima H, Okumura M (1996) Increased expression of insulin-like growth factor 2 in hepatocellular carcinoma is primarily regulated at the transcriptional level. Lab Invest 75:307-311

Sohda T, Oka Y, Iwata K, Gunn J, Kamimura S, Shijo H, Okumura M, Yun K (1997) Co-localisation of insulin-like growth factor II and a proliferation marker, MIB-I in human hepatocellular carcinoma cells. J Clin Pathol 50:135-137

Sporn MB, Roberts AB (1985) Autocrine growth factors and cancer. Nature 313:745-747

Steenman MJ, Rainier S, Dobry CJ, Grundy P, Horon IL, Feinberg AP (1994) Loss of imprinting of IGF2 is linked to reduced expression and abnormal methylation of H19 in Wilms' tumour. Nat Genet 7: 433-439

Su Q, Liu Y-F, Zhang J-F, Zhang S-X, Li D-F, Yang J-J (1994) Expression of insulin-like growth factor II in hepatitis B, cirrhosis and hepatocellular carcinoma: Its relationship with hepatitis B virus antigen expression. Hepatology 19:788-799

Sussenbach JS, Steenbergh PH, Jansen E, Holthuizen P, Meinsma D, van Dijk MA, Gloudemans T (1991) Structural and regulatory aspects of the human genes encoding IGF-I and IGF-II. Adv Exp Med Biol 293:1-14

Takeda S, Kondo M, Kumada T, Koshikawa T, Ueda R, Nishio M, Osada H, Suzuki H, Nagatake M, Washimi O, Takagi K, Takahashi T, Nakao A, Takahashi T (1996) Allelic-expression imbalance of the insulin-like growth factor 2 gene in hepatocellular carcinomas and underlying disease. Oncogene 12:1589-1592

van Dijk MA, van Schaik FMA, Bootsma HJ, Holthuizen P, Sussenbach JS (1991) Initial characterization of the four promoters of the human insulin-like growth factor II gene. Mol Cell Endocrinol 81:81-94

Viel A, Giannini F, Tumiotto L, Sopracordevole F, Visentin MC, Boiocchi M (1992) Chromosomal localisation of two putative 11p oncosuppressor genes involved in human ovarian tumours. $\mathrm{Br} \mathrm{J}$ Cancer 66:1030-1036

Vu TH, Hoffman AR (1994) Promoter-specific imprinting of the human insulin-like growth factor-II gene. Nature 371:714-717

Wilkins RJ, Molenaar AJ, Ohlsson R, Reeve AE, Yun K, Becroft DMO (1989) Wilms' tumorigenesis, insulin-like growth factor II gene expression and blocked differentiation. Cancer Cells 7:321-325

Winqvist R, Mannermaa A, Alavaikko M, Blanco G, Taskinen PJ, Kiviniemi H, Newsham I, Cavenee W (1993) Refinement of regional loss of heterozygosity for chromosome $11 \mathrm{p} 11.5$ in human breast tumors. Cancer Res 53:4486-4488

Zhang Y, Tycko B (1992) Monoallelic expression of the human H19 gene. Nat Genet 1:40-44 